This is an electronic reprint of the original article. This reprint may differ from the original in pagination and typographic detail.

Author(s): Pesu, Laura; Viljaranta, Jaana; Aunola, Kaisa

Title: $\quad$ The role of parents' and teachers' beliefs in children's self-concept development

Year: $\quad 2016$

Version:

Please cite the original version:

Pesu, L., Viljaranta, J., \& Aunola, K. (2016). The role of parents' and teachers' beliefs in children's self-concept development. Journal of Applied Developmental Psychology, 44(May-June), 63-71. https://doi.org/10.1016/j.appdev.2016.03.001

All material supplied via JYX is protected by copyright and other intellectual property rights, and duplication or sale of all or part of any of the repository collections is not permitted, except that material may be duplicated by you for your research use or educational purposes in electronic or print form. You must obtain permission for any other use. Electronic or print copies may not be offered, whether for sale or otherwise to anyone who is not an authorised user. 
The Role of Parents' and Teachers' Beliefs in Children's Self-Concept Development 


\begin{abstract}
This study examined to what extent parents' and teachers' beliefs about children's abilities predict children's self-concept of math and reading ability development during the first grade, and whether these predictions depend on the child's gender and level of performance. One hundred fifty-two children and their parents and teachers were followed across first grade. The results showed, first, that the associations between teachers' beliefs and children's subsequent self-concept of ability depended on the level of the children's performance. Among high-performers, the higher the teachers' beliefs about their students' abilities in reading or in math, the higher the subsequent level of self-concept of ability. Among low-performers no association was found between teachers' beliefs and students' selfconcept of ability in either reading or math. Second, mothers' and fathers' beliefs were not predictive of children's self-concept of math and reading ability during first grade. Overall, these results suggest that during the first grade it is teachers' rather than parents' beliefs, that play a role in children's selfconcept of ability. In teacher education, emphasis should therefore be placed on the importance of supporting children's developing self-concept as well as teaching new academic skills.
\end{abstract}

Keywords: self-concept of ability, first grade, teacher's beliefs, mother's beliefs, father's beliefs 


\section{The Role of Parents' and Teachers' Beliefs in Children's Self-Concept Development}

Previous research has consistently shown that students' self-perceptions, such as their selfconcept of ability, direct their behavior and effort in learning situations (e.g., Atkinson 1964; Bandura 1986; Eccles et al. 1983; Wigfield, Eccles, Schiefele, Roeser, \& Davis-Kean 2006). It has been suggested that self-concept of ability develops in interaction with other people (Dermitzaki \& Efklides, 2000), such as parents and teachers. For example, parents' attitudes and beliefs (McGrath \& Repetti, 2000; Tiedemann, 2000) as well as teachers' beliefs (Bohlmann \& Weinstein, 2013; Burnett, 2003; Lehtinen, Vauras, Salonen, Olkinuora \& Kinnunen, 1995; Tiedemann, 2000) have been shown to be associated with children's self-concept of ability development. Moreover, parental beliefs have been shown to play an even stronger role in children's self-concept of ability development than children's previous level of performance (e.g., Frome \& Eccles, 1998). However, although many studies have examined the roles of parents and teachers in the development of children's self-concept of ability, few efforts have been made to examine these among the youngest students (Wigfield et al., 1997). Moreover, although it might be that high performing children benefit from different kinds of teacher and parental support and feedback than low performing children (Bohlmann \& Weinstein, 2013), the possibility that the role of parents' and teachers' beliefs is different depending on the level of children's performance has thus far not been considered. Consequently, the aim of the present study was to examine the extent to which parents' and teachers' beliefs about children's abilities are associated with children's academic self-concept development during the first grade of primary school and whether these associations differ according to the level of the children's performance.

\section{Self-Concept of Ability}

Self-concept of ability refers to an individual's perception of his or her competence in a certain domain (Wigfield \& Eccles, 2000). Earlier, the research emphasis was on a global construct, such as 
general self-concept or self-esteem (for a review, see Bong \& Skaalvik, 2003); however, the notion that self-concept is global in nature has since been criticized for overlooking the important distinctions that children make between activity domains (Harter, 1982). Shavelson, Hubner and Stanton (1976) proposed a multidimensional, hierarchical model of self-concept, with global self-concept at the apex that can be subdivided into academic and nonacademic components. These in turn can be further divided into subdomains, that is, academic self-concept into self-concepts for specific school subjects, and nonacademic self-concept into subdomains such as physical, social and emotional self-concepts. In the present study, self-concept is also approached subject-specifically, as numerous empirical studies have provided support for the domain-specificity of self-concept, meaning that there are distinct math and verbal domains in academic self-concept (Arens, Yeung, Craven, \& Hasselhorn, 2011; Marsh \& O’Neil, 1984).

Eccles' expectancy-value theory provides one theoretical framework for students' selfperceptions in the academic context. According to this theory (Eccles et al., 1983; Eccles \& Wigfield, 1995; Wigfield \& Eccles, 2000), individuals' performance and academic choices are explained not only by the extent to which they value the activity in question but also by the beliefs they have about their own abilities (expectancies for success). Expectancies are presumed to have a direct influence on different academic outcomes, such as performance (Wigfield \& Eccles, 2000). Moreover, ability beliefs and the perceived difficulty of a task are assumed to influence expectancies. Eccles et al. (1983) defined ability beliefs as the individual's perception of his/her current competence at a given activity. Hence, the theoretical difference between ability beliefs and expectancies for success is that ability beliefs focus on present ability while expectancies focus on the future. Although, expectancies and ability beliefs are theoretically distinct concepts, empirically they have not been found to be separate 
(Eccles et al., 1983; Wigfield \& Eccles, 1992; 2000). In the present study, we use the term "selfconcept of ability" to refer to task-related perceptions of one's abilities (Wigfield \& Eccles, 2000).

Previous studies have shown that children have very positive and even unrealistic perceptions of their abilities during the first years of primary school (Aunola, Leskinen, Onatsu-Arvilommi, \& Nurmi, 2002; Wigfield \& Eccles, 2000). As they grow older, their perceptions of their abilities become more realistic and more negative (Dweck, 2002; Jacobs, Lanza, Osgood, Eccles, \& Wigfield, 2002). For example, Dweck (2002) showed that children start to view their abilities more realistically at the age of 7-8. According to Dweck (2002), one reason for this change is that, around this age, children become more responsive to performance feedback. The stability of inter-individual differences in self-concept has also been shown to increase over time. For example, Aunola et al. (2002) found that children's relative standings on their self-concept of ability were very unstable during their first months of primary school, but became relatively stable by the end of the first grade. Overall, the first grades of primary school seem to be an important developmental period for the development of self-concept of ability. Besides the development of cognitive reasoning skills during this period, a whole new social context becomes a part of the child's everyday life: the child starts to receive everyday feedback from teachers and classmates become points of comparison.

\section{The Role of Parents and Teachers}

It has been suggested that self-perceptions are formed in interaction with one's environment, and are influenced by evaluations by significant others and by reinforcements of, and attributions for, one's behavior (Bong \& Skaalvik, 2003; Eccles et al. 1983; Gniewosz, Eccles, \& Noack, 2014; Shavelson et al., 1976). For example, according to the Eccles' Expectancy-value model, parental beliefs play an important role in students' ability beliefs (Eccles, 1993). According to the expectancyvalue model, the links between parental beliefs and students' achievement-related perceptions can be 
explained by at least two mechanisms (Eccles, 1993; Eccles et al., 1983; Simpkins, Fredricks, \& Eccles, 2012): First, parents can communicate their beliefs to their children directly by encouraging them to do better in school or by giving them positive feedback when they do well in school (Gniewosz, Eccles, \& Noack, 2014); second, parents may communicate their beliefs indirectly through the way they behave with their children, such as by the act of helping children with their schoolwork.

Empirical support has also been found for the assumption that parents' beliefs about their children's academic performance are associated with children's subject-specific self-concept of ability (Eccles Parsons, Adler, \& Kaczala, 1982; Frome \& Eccles, 1998; Gniewosz, Eccles, \& Noack, 2012; Jacobs, 1991; Lau \& Pun, 1999; McGrath \& Repetti, 2000; Phillips, 1987). For example, among fifthto eleventh-graders, Eccles Parsons et al. (1982) found that parents who considered that their child did not perform well in math, and that math was difficult for their child, had children whose math-related self-concept was particularly low. Similarly, parents' beliefs have been found to be positively related to sixth-grade children's self-concept of ability in English (native language) (Frome \& Eccles, 1998). These associations remained even after controlling for the previous level of children's performance (Frome \& Eccles, 1998). Recently, Gniewosz et al. (2014) found that parents' perceptions of their children's abilities mediated the connections between school grades and students' academic selfconcept in both math and native language among fifth- to seventh-graders.

Some gender differences in parental beliefs have also been reported. For example, parents tend to think that mathematics is more difficult for girls than for boys (Eccles Parsons et al., 1982; Eccles \& Jacobs, 1987; Gunderson, Ramirez, Levine, \& Beilock, 2012), independently of children's actual performance in mathematics (Eccles, 1993; Eccles Parsons et al., 1982), a belief which has been shown to impact girls' self-perceptions in mathematics (Jacobs, 1991). Girls, in turn, are typically thought to do better in native language (Gniewosz et al., 2014; Wigfield \& Eccles, 1992). It has been further 
shown that parents of girls tend to overestimate and parents of boys to underestimate their child's ability in native language (English) (Frome \& Eccles, 1998). These studies on gender differences in parental beliefs have not focused on children who have just begun their school career, and hence this age group is the focus of the present study.

Besides parents' beliefs, teachers' beliefs and expectations have also been shown to impact students' self-perceptions. For example, teachers' expectations of students' abilities have been shown to relate to students' self-concept of abilities in both mathematics (e.g., Madon et al., 2001) and reading (e.g., Brattesani, Weinstein, \& Marshall, 1984). Madon et al. (2001) found that teachers' positive beliefs predicted positive changes in sixth-grade students' mathematics self-perceptions. Brattesani et al. (1984), in turn, found that teachers' expectations were positively associated with students' own expectations and performance in reading among fourth- to sixth-grade students. Moreover, it has been found that teachers' evaluations play a larger role in third- to fourth-graders' general self-concept (i.e., children's perceptions of their general school-related ability) than parents' perceptions (Spinath \& Spinath, 2005). Teacher evaluations of student's performance have also been found to correlate highly with objective measures of school performance (e.g., Hoge \& Coladarci, 1989). However, there is evidence that although teachers are good at perceiving students' visible performance in the classroom (Hoge \& Coladarci, 1989), they do not necessarily perceive their students' underlying cognitive capacities. For example, it has been shown that teachers are not good at detecting underachievers, that is, students who have high abilities but show low school performance (e.g., Rost \& Hanses, 1997).

Like parents, teachers also seem to show a gender bias in their beliefs about students' abilities, at least in the domain of mathematics (for a review, see Li, 1999; Gunderson et al., 2012). Teachers have been shown to be prone to stereotype mathematics as a male domain ( $\mathrm{Li}, 1999)$. For example, Tiedemann (2000) found that German teachers of third- through fourth-grade students believed that 
mathematics is a more difficult subject for girls than for boys, and that average-achieving girls are less logical than equally achieving boys. It has been found that even preschool-aged children are susceptible to these kinds of gender stereotypes, at least in the mathematics domain (Ambady et al., 2001).

Overall, both parents' and teachers' beliefs have been shown to be associated with students' self-concept of ability, while some gender differences, favoring boys over girls in mathematics and girls over boys in native language (English), in these beliefs have also been found (Frome \& Eccles, 1998). The earlier research on the topic has, however, some limitations. First, research focused on the role of both teachers' and parents' beliefs is rare (for an exception, see Spinath \& Spinath, 2005). There is, however, some evidence indicating that the importance of teacher evaluations for children's ability self-perceptions may increase and the importance of parents' evaluations decrease during grades 1-4 (Spinath \& Spinath, 2005). Secondly, although many studies have examined the antecedents of selfconcept of ability, few efforts have been made to examine these among the youngest students (Wigfield et al., 1997). Because self-concept of ability becomes stable very early on during the school career (Aunola et al., 2002), the first school year in particular is an important period in which to track its development. Consequently, the first aim of the present study was to examine the role of parents' and teachers' beliefs about children's abilities in reading and mathematics in the development of children's self-concept of ability during the first grade of primary school. Possible differences in these associations depending on child's gender were also investigated.

\section{The Moderating Role of Child's Level of Performance}

Previous research on the relation between parental and teacher beliefs and child's selfperceptions has assumed that high teacher (e.g., Tiedemann, 2000) and parental beliefs (Eccles Parsons et al., 1982; Frome \& Eccles, 1998) are positively associated with a child's own beliefs. However, because children's level of cognitive ability has been shown to be positively related to both their self- 
perceptions (Bohlmann \& Weinstein, 2013) and the teacher-child relationship (Jerome, Hamre, \& Pianta, 2009), there are grounds for assuming that - because cognitive abilities strongly correlate with academic performance (Dermitzaki \& Efklides, 2000) - the associations between teacher beliefs and child's self-perceptions are not necessarily the same for low- and high-performing children. Also, according to Bohlmann and Weinstein (2013), children's cognitive reasoning skills affect the way they perceive, interpret, and attribute meaning to teachers' actions. They argued that "interpreting performance feedback may depend on the ability to coordinate multiple forms of feedback and logically analyze the meaning of positive versus negative messages in application to the self' (p. 290). Following this line of reasoning, it might be assumed that high-performing children are more prone to be influenced by adults' beliefs than low-performing children as (due to their cognitive abilities) they are able to make more accurate interpretations of adults' feedback and performance. However, no studies thus far have investigated whether the impact of parental and teacher beliefs on children's selfperceptions differ according to the level of the child's performance. Consequently, the second aim of the present study was to examine whether the role of parents' and teachers' beliefs in the development of children's self-concept of ability during the first grade of primary school differs according to the level of the child's performance.

The present study was carried out in Finland. Finnish children start their education by attending pre-school (kindergarten), which begins in the year of the child's sixth birthday. One year later, in the year of their seventh birthday, children make the transition to compulsory comprehensive school. One important difference in the transition from kindergarten to primary school in Finland compared to some other countries is that Finnish children are one to two years older than their counterparts in many other countries when they start formal education. Hence, the first graders participating in the present study are 7- to 8-year-olds. 


\section{Method}

\section{Participants}

The participants of the study consisted of 152 first graders ( 79 girls, 73 boys; age ranging from 6 years 9 months to 8 years 8 months, $M=7.5$ years) and their teachers and parents. The sampling was started by contacting 334 first-grade teachers in three medium-sized towns in Finland and asking them to participate in the study. One hundred sixty-six teachers agreed to do so and signed a written consent. Next, one student from each classroom $(n=166)$ was randomly selected, and the students' parents were asked to give their consent to their child's participation. If the parents did not respond or refused consent, another child from the classroom was selected, again at random, and his or her parents were contacted. This procedure continued until one student from each classroom was selected. One hundred fourteen parents gave their consent in the first round, 33 in the second round, 15 in the third round, and 4 in the fourth round. Of this total of 166 children, 14 children and their mothers were omitted from the analyses because the children were in special education classrooms. Thus, the final sample comprised 152 children in normal classrooms, and their mothers, fathers and teachers. The reason for selecting only one child per classroom was that, as part of the data gathering, teachers were asked to fill in diary questionnaires on their interaction with the target children. It was considered that having more than one child per classroom would add excessively to the teacher's workload.

The families were fairly representative of the general Finnish population. $52 \%$ of the mothers and $31 \%$ of the fathers had at least an upper secondary school education, $47 \%$ of the mothers and $66 \%$ of the fathers had at least a comprehensive school education (all 9 grades), and $1 \%$ of the mothers and $3 \%$ of the fathers had not completed comprehensive school. $78 \%$ of the families were nuclear families (67 married, 11 cohabiting parents), 12\% blended families, and 10\% single-parent families. The number of children per family ranged from 1 to $10(M=2.39, S D=1.03)$. 
Women comprised $94.8 \%$ of the participating teachers. Mean years as a teacher was 16.0 years $(S D=10.5$ years $)$ and mean years as a first- or second-grade teacher was 7.5 years $(S D=7.5$ years).

The children were interviewed in the fall (October; Time 1) and spring (April; Time 2) semesters of their first-grade year on their self-concept of ability in math and reading. The children's performance in reading and mathematics was also tested in the fall semester (Time 1). The children's mothers, fathers, and teachers answered a questionnaire on their beliefs and expectations concerning the child's abilities and provided some background information in the fall semester (October; Time 1). Mothers and fathers were paid 50 EUR (54.20 USD) and teachers 100 EUR (108.30 USD) for their participation in the study.

\section{Measures}

Self-concept of ability. Children's mathematics- and reading-related self-concepts were measured using a questionnaire modified from the scale developed by Eccles et al. (Wigfield et al., 1997). Three questions measured mathematics-related self-concept (e.g., How good are you at mathematics and counting?) and three reading-related self-concept (e.g., How good are you at reading and knowing letters?). After each question, the child was shown a set of five squares increasing in size from a very small square which was scored 1 ("not very good") to a large square scored 5 ("very good"). The child was asked to answer by pointing to the square which best described his/her skills in a particular school subject. Cronbach's alpha reliabilities were .55 and .66 for mathematics-related selfconcept and .70 and .53 for reading-related self-concept at Time 1 and Time 2, respectively.

Mothers', fathers' and teachers' beliefs. Mothers, fathers, and teachers were asked for their expectations concerning the target child's success at school via questionnaires (Aunola et al., 2002, 2003). The scale consisted of a set of items modified from the questionnaires used by Eccles Parsons et al. (1982). Two of these items measured expectations concerning the children's reading skills (How 
well do you think your child / the target child is doing in reading?; How well do you think your child / the target child will do in reading later in school?) and two items measured expectations concerning the children's mathematics skills (How well do you think your child / the target child is doing in mathematics?; How well do you think your child / the target child will do in mathematics later in school?). Each parent, separately, and teachers answered the questions on a 5-point Likert-scale $(1=$ "poorly", 5 = "very well"). Cronbach's alphas for their beliefs in mathematics and reading were: for mothers .74 and .75 , respectively; for fathers .72 and .76 ; and for teachers .88 and .88 .

Children's mathematics performance. Children's mathematics performance was measured by two tests:

(1) Children's knowledge of cardinal numbers and basic mathematical concepts (e.g., equal, more, less), was measured by 11 tasks that became progressively more difficult (Ikäheimo, 1996). In each task, the children were shown a picture of a set of balls and asked to draw a specific number of balls in the blank space provided (e.g., Draw as many balls as there are in the model; Draw five balls fewer than there are in the model; Draw four balls more than there are in the model). One point was given for each correct answer.

(2) In the basic arithmetic test, children's skill level in basic arithmetic was assessed using a set of visually presented addition (e.g., '9 + 3 = ?’; ' $86+?=93$ ') and subtraction (e.g., '11 - 2 = ?'; ‘57 - ? $\left.=48^{\prime}\right)$ tasks. The test comprised a total of 20 tasks. The children were asked to complete as many of the tasks as they could. One point was given for each correct answer.

A total score for children's performance in mathematics in the fall semester (Time 1) of first grade was arrived at by calculating a sum score from the points scored in the knowledge of cardinal numbers and basic arithmetic tests. The split-half reliability for the score was .86 . The test-retest reliability of the measure was $.70(p<.001)$. 
Children's reading performance. Children's reading performance was assessed by two subtests:

(1) In the reading words test, children were asked to read aloud a set of 20 words of progressive difficulty. The level of difficulty was increased mainly through the use of words of increasing length (e.g., "ja" (and), "isä" (dad), "ikkuna" (window), "tulitikku" (match)). The test was discontinued if the child was unable to read four successive items correctly. One point was given for each correctly read word, yielding a maximum score of 22 . The split-half reliability for the reading words test was .80. This subtest is known to be sensitive to the early stages of reading (see Leppänen, Niemi, Aunola, \& Nurmi, 2004).

(2) In the oral reading fluency test, the task for the children was to read aloud, to their best ability, a short story in an individual test situation. The story consisted of 57 words. The score for oral reading fluency was computed by dividing the number of words read correctly by the time (in seconds) it took for the child to read the whole story. This score has been shown to correlate with teacher assessments of children's reading performance $(r=.66-.79$; Parrila, Aunola, Leskinen, Nurmi, \& Kirby, 2005). This subtest is known to be sensitive to more advanced reading skills (see Leppänen et al., 2004).

A total score for children's reading performance in the fall semester of the first grade (Time 1) was arrived at by calculating a mean score from the standardized scores (z-scores) for reading words and oral reading fluency. The Pearson moment correlation between the two subtests was $.41(p<.001)$. The test-retest reliability of the measure was $.56(p<.001)$.

\section{Results}

The means $(M)$, standard deviations $(S D)$, and correlations of the variables used are shown in Table 1. The correlations (Table 1) showed positive associations between self-concept of ability at the 
end of the first grade (Time 2) and children's previous level of performance and mothers', fathers' and teachers' beliefs in both the domains of reading and mathematics (Time 1), justifying the further analyses examining to what extent children's previous level of performance and parents' and teachers' beliefs predict the development of children's self-concept of ability.

--- Insert Table 1 about here---

The research questions were analyzed using hierarchical regression analysis. The effect of teachers', mothers', and fathers' beliefs on children's self-concept development was first tested each in separate analyses to find out which of these belief variables are potential predictors of children's selfconcept development. In these analyses, children's self-concept of ability in a specific school subject at the end of the first grade (Time2) was predicted by their self-concept of ability in that subject in the fall (Time1), academic performance in that subject in the fall (Time1), gender, and mothers' / fathers' / teachers' beliefs in the fall (Time1). Each variable was entered stepwise in the analysis. In order to determine whether any connections observed between parental or teacher's beliefs and the child's subsequent level of self-concept of ability was influenced by the child's gender or by the child's level of performance, the related interaction terms (Gender X Belief or Academic Performance X Belief) were added to the analysis in the last step. Each interaction term was tested in a separate analysis. The analysis was carried out separately for mathematics-related self-concept of ability and reading-related self-concept of ability. All the predictor variables were standardized before they were added into the regression models and before calculating any interaction terms. In the tested models, no serious multicollinearity among predictor variables was evident (range of tolerance values in different models was .40-.96; range of VIF values in different models was 1.04-2.66). The results of the analyses on the role of teachers' beliefs for self-concept of reading ability are shown in Table 2 and for self-concept of 
mathematics ability in Table 3. The results of the analyses concerning the role of mothers' and fathers' beliefs are presented in the text.

To find out whether the results remain the same if teachers' and parental beliefs are included simultaneously in the models, analyses in which teachers' and parental beliefs were included in the same model were also carried out. In these models, the beliefs of different agents, i.e. beliefs of mothers, fathers, and teachers, were entered into the models stepwise. In this context, different kinds of models were tested with different order of the belief-variables in the model. Because the results of these more complex models did not differ from the results found when testing the effects of mothers', fathers' and teachers' beliefs separately, we report in detail only the more parsimonious models that were tested first.

---Insert Table 2 about here---

--- Insert Table 3 about here---

\section{Reading-related self-concept}

The results for reading-related self-concept showed, first, that children's self-concept at the end of the first grade was not predicted by either their previous self-concept of reading ability, previous reading performance, or gender (see Table 2). Second, the results showed that, after controlling for the previous level of self-concept and reading performance, mothers' $(\beta=0.10, p=.35)$ and fathers' beliefs $(\beta=0.19, p=.13)$ did not predict children's self-concept at the end of the first grade. No Parental Belief X Gender or Parental Belief X Performance interaction effects were found either. Third, the results showed that teachers' beliefs marginally $(p<.10$; see Table 2$)$ predicted children's subsequent reading-related self-concept: the higher the teachers' beliefs concerning children's reading ability at the beginning of the first grade, the higher the self-concept of reading ability the children reported at the end of the first grade, after controlling for the previous level of self-concept and reading 
performance. The results showed further, however, that the interaction term Teacher Belief X Reading Performance was statistically significant, suggesting that the association between teachers' beliefs and children's subsequent self-concept of ability differed depending on the level of the child's performance. To examine this interaction effect further, Aiken and West's (1991) procedure was used. In this procedure, simple slopes for the teacher belief variable in the prediction of children's reading selfconcept were calculated and presented using standardized scores separately for children who showed either low $(-1 S D)$ or high $(+1 S D)$ levels of reading performance. The results are shown in Figure 1.

---- Insert Figure 1 about here----

The results (Figure 1) showed that among children with high reading performance, teachers' beliefs about the children's success in reading at Time 1 positively predicted the children's reading self-concept at Time $2(t=2.84, p<.01)$ : the higher the teachers' beliefs at the beginning of the first grade (Time 1), the better the children's self-concept of ability at the end of the first grade (Time 2), after controlling for the previous level of self-concept of ability (Time 1). Among children with low initial reading performance, in turn, teachers' beliefs in the child's success in reading did not show this positive impact $(t=1.05, p=0.30)$.

\section{Mathematics-related self-concept}

The results (see Table 3) for mathematics-related self-concept showed, first, that children's selfconcept of ability at the end of the first grade (Time 2) was positively predicted by their previous level of self-concept of ability (Time 1) but not by their previous level of mathematics performance (Time 1). Second, neither mothers' $(\beta=0.16, p=.06)$ nor fathers' beliefs $(\beta=0.05, p=.62)$ (Time 1$)$ predicted children's subsequent self-concept of mathematics ability after controlling for the previous level of self-concept and mathematics performance. No Parent Belief X Gender or Parent Belief X Performance interaction effects were found either. Third, the results showed that although teachers' 
beliefs had no main effect on the self-concept of mathematics ability, the interaction term Teacher Belief X Mathematics Performance was statistically significant, suggesting that the association between teachers' beliefs and children's self-concept of mathematics ability differed depending on the level of the child's mathematics performance. To examine this interaction effect further, simple slopes for the teacher belief variable in the prediction of children's mathematics self-concept were calculated and presented using standardized scores separately for children who showed either low $(-1 S D)$ or high (+1 $S D$ ) levels of mathematics performance. The results are shown in Figure 2.

---- Insert Figure 2 about here----

The results showed (see Figure 2) that among children with high mathematics performance, teacher's positive beliefs about these children's success in mathematics (Time 1) positively predicted the development of the children's self-concept of mathematics ability $(t=3.77, p<.001)$ : among high performing children, the higher the teachers' beliefs at the beginning of the first grade, the higher the children's subsequent self-concept of mathematics ability at the end of the first grade, after controlling for the previous level of self-concept of ability and mathematics performance. Among children with lower initial mathematics performance, teachers' beliefs in child's success in mathematics did not have this positive impact $(t=1.11, p=.91)$.

To account for the possible impact of parental socioeconomic status (SES) on the results, all the analyses were also carried out with the inclusion of SES as one of the predictor variables. Controlling for SES did not, however, impact any of the results reported above. Finally, all analyses were also carried out by including mothers', fathers', and teachers' beliefs as predictor variables in the same analyses (i.e., their effects were tested simultaneously). The pattern of results remained the same as reported above.

\section{Discussion}


The present study aimed to contribute to the literature on the topic by examining what role mothers', fathers' and teachers' beliefs concerning children's abilities in reading and mathematics might play in the development of children's self-concept of ability during the first grade. Also examined was whether these possible associations are influenced by the child's gender or level of performance. The results showed that the role of teachers' beliefs on children's self-concept of mathematics and reading ability was dependent on the level of the children's performance. Among high-performing students, higher teacher beliefs predicted subsequent positive self-concept of ability in both reading and mathematics, whereas among low-performing students, no such positive association was observed. Although parents' beliefs were associated with children's self-concept of mathematics and reading abilities at the beginning of the first grade, they were not found to predict children's selfconcept of ability by the end of the first school year.

\section{The Role of Teachers' Beliefs in Children's Self-Concept Development}

The results of the present study showed, first, as could be expected on the basis of previous studies, that both teachers' and parents' beliefs about children's abilities were positively correlated with children's self-concept of ability in mathematics (Eccles Parsons et al., 1982; Frome \& Eccles, 1998; Tiedemann, 2000) and reading (Frome \& Eccles, 1998) among Finnish first-graders. Further, the results indicated that although parents' beliefs were positively associated with children's self-concept, it was teachers' beliefs in particular that predicted children's self-concept of ability by the end of the first school year in both reading and mathematics. This prediction was, however, dependent on the level of the children's performance. Among children whose performance level was initially high, teachers' beliefs positively predicted self-concept of ability: the higher the teachers' beliefs, the higher the students' subsequent self-concept of ability. Among children with a low performance level this 
positive prediction was not found. This result was obtained for both reading and mathematics. The finding of a positive relationship between teachers' beliefs and children's self-concept of ability is in line with the findings of several previous studies (Blumenfeld, Pintrich, Meece, \& Wessels, 1982; Brattesani et al., 1984; Madon et al., 2001; Spinath \& Spinath, 2005). However, the present results add to the literature by showing that the positive association of teachers' beliefs with students' self-concept was particularly evident among high-performing students.

The result showing no relationship between teachers' beliefs and students' self-concept of ability among low performing children, in turn, is interesting and has several possible explanations. First, it is possible that teachers communicate their beliefs, even where they are equally positive, differently to children with different performance levels. If so, this means that the effect of these beliefs will also be different for children who perform differently. Previous research has shown that teachers treat low- and high-performers differently. For example, Blöte (1995) found that both students and teachers perceived that low-performers receive more help and support from their teachers and are put under less pressure than high-performers. Second, Wigfield and Harold (1992) found that teachers' perceptions of children and children's own achievement self-perceptions were only modestly related. According to them, the reason for these modest relations could be that teachers' beliefs form only one source of information for children; namely, children also get information, for example, from their own previous performance, the performance of peers, and messages from their parents. Thus, it is possible that low-performing children do not benefit from positive teacher beliefs because other feedback concerning their skills (e.g., performance outcomes, peer influences and comparisons) might have a stronger effect on their self-concept than teachers' beliefs. Third, it is possible that students interpret teacher's cues about their beliefs differently depending on their level of performance. Students with a poor level of performance might see positive teacher feedback as special attention given by the teacher 
because the student is doing badly at school. For example, a child might interpret positive feedback from the teacher, not as a reflection of her or his actual performance, but rather as signaling a need for extra practice, trying harder, etc. In contrast, students with a high level of performance may interpret positive teacher feedback as an indication of their high achievement. Fourth, false beliefs by teachers could explain why teachers' high beliefs had no impact on students' self-concept of ability among lowperforming children. It might be that, in the case of low-performers, teachers' beliefs in their success give these children the wrong messages about their level of performance, which would explain why teachers' positive beliefs had no positive impact on the self-concept of low-performing students. On the other hand, abilities can be seen not only as stable internal capacities but also as affected by, for example, effort (Dweck, 2002). Thus, children who were categorized as low-performers in this study might have the potential for doing better if they put more effort into their tasks. Seen from this perspective, teachers can believe in low-performing students' potential for achievement, without having a false perception of the student. It is also possible that teachers' beliefs and high-performing students' self-concepts concur because there might be more frequent daily communication taking place between teachers and high-performing students concerning students' performance. This interaction might also be more constructive and positive in case of high performing students. Finally, as Bohlmann and Weinstein (2013) argue, children's cognitive abilities influence their perceptions and interpretations of teachers' actions. Accordingly, it might be assumed that high-performing children have better cognitive abilities to accurately perceive and interpret teachers' beliefs from teachers' behaviors. However, it is possible that our data include underachieving students, that is, students who show low performance despite having the potential to do better. Among such underachievers, poor cognitive competence in interpreting social cues cannot be adduced to explain the finding. 
The present study is one of the few to offer information about the possible role of teachers in the case of young students. Most previous studies have been conducted with students older than first graders. However, the age of the present students, i.e., 7-8 years, can be assumed to be an important developmental period in which to study the role of teachers in children's self-perceptions, as it is during this period that children become more responsive overall to performance feedback (Dweck, 2002). Our results are in line with this observation on children's development by showing that teacher beliefs are related to the self-concept development of 7- and 8-year-olds, at least among those who are performing relatively well in school.

\section{The Role of Parents' Beliefs in Children's Self-Concept Development}

Based on the literature, it was surprising that in the present study parents' beliefs did not predict children's self-concept of mathematics and reading ability development. This result contradicts previous findings indicating that parents' beliefs about children's abilities also play a role, stronger even than that of children's previous level of performance, in children's self-concept of math and reading ability development (e.g., Frome \& Eccles, 1998). It has been argued that parents' perceptions concerning their children are a major determinant of children's self-beliefs (e.g., Eccles Parsons et al., 1982; Frome \& Eccles, 1998). However, parents do not have the same first-hand social comparison information as teachers about children's school achievement (Spinath \& Spinath, 2005). One explanation for the present result that parental beliefs did not predict children's self-concept of ability is that the connection between parental beliefs and students' self-concept varies at different ages (e.g., Gniewosz et al., 2012). Previous research on the role of parental beliefs in children's self-perceptions has focused on older school-aged children than those in the present study. Eccles (1993) points out that parents rely heavily on objective feedback (e.g., school grades) when forming their impressions of their children's abilities. It is possible that during the first school years not only children but also parents 
form ideas about children's abilities. Thus, it might be that the first school years are crucial in the development of both children's self-concept of ability and parental belief systems concerning their children. This could explain why the teacher's role in the development of children's self-concept of ability was emphasized during the first grade. Furthermore, it is should be noted that self-concept was examined in the domains of mathematics and reading ability in the present study. Teachers assess students' achievement frequently and obtain much information about students' learning in daily classroom situations. Thus, teachers have first-hand information about students' mathematics and reading abilities. Teachers can observe the learning processes and achievement of their students, and they frequently give students information on their academic performance. It is possible that parents have a stronger impact on students' self-concept development in some other domains. In the future, it would be interesting to examine the effects of both parents' and teachers' beliefs simultaneously over a longer period of time and across different self-concept domains in order to gain a better understanding of the developmental dynamics between children's performance, adults' beliefs about children's performance, and children's self-concepts.

\section{Gender Differences}

In the present study, no effect was found for the child's gender on the development of selfconcept of ability in either mathematics or reading. This is inconsistent with the results of previous studies, where girls have shown a poorer self-concept of mathematics ability (Eccles Parsons et al., 1982) but a higher self-concept of English (native language) than boys (Frome \& Eccles, 1998). In this connection, it is noteworthy that it is explicitly stated in the Finnish national curriculum guidelines that teachers should focus on motivating both boys and girls equally to learn and to help them build a positive self-concept. Moreover, since Finland can be considered an egalitarian culture (Chiu \& Klassen, 2009; Chiu \& Klassen, 2010), there might be fewer gender differences overall. This could 
offer one explanation for the absence of a gender effect on the development of self-concept of ability. Thus, it is possible that gender differences in children's self-concept of ability development are weaker in the Finnish culture compared to, for example, the North-American culture. Moreover, gender did not have an effect on the relationship between teachers' and parents' beliefs and children's self-concept of ability development. This result is in line with a previous study on Finnish students that found no difference in the associations of parental causal attributions with children's self-concept of math ability between parents of boys and parents of girls (Rytkönen, Aunola, \& Nurmi, 2007).

\section{Limitations}

The present study has its limitations. First, the reliability of self-concept measures was not very high. One factor that may have reduced the reliability in the present study was the small number of items measuring each construct (see Wells \& Wollack, 2003). Second, the study was carried out in just one educational setting, Finland. Because it is possible that parental and teacher beliefs play a different role in students' self-perceptions in different educational settings and cultures, further cross-cultural research on the topic is needed. Third, the children in this study were followed up for one year only. It would be valuable to utilize a longer time frame in future studies. Fourth, in this study self-concept of ability was studied with quantitative methods, i.e., through interviews and questionnaires. Qualitative methods might capture the phenomenon in a different way. Since self-concept includes perceptions of oneself, and is multidimensional, children can find it hard to express their perceptions by answering direct questions. It might be easier for children to express their perceptions through, for example, stories or pictures, which could then be analyzed qualitatively. Such an approach could make for a broader understanding of students' perception. Fifth, although a longitudinal procedure was used, it is possible that some third factor not controlled for explains the predictions found. One should, therefore, be cautious before making any judgements about the possible causality of our results. Finally, since the 
students participating in the present study were quite young, it was not possible to reliably measure how they perceived their teachers' beliefs. Information about these perceptions might provide some explanations for the results. Consequently, in future research there is a need to study whether children's perceptions of their teachers' beliefs impact students' self-perceptions.

\section{Practical Implications}

The results of the present study can be capitalized on in teacher education programs. For example, the fact that teachers' beliefs are associated with children's self-concept of ability development, particularly among high-performing children, suggests that these beliefs may also contribute to the development of underachievement among high-performing children, and hence that they should be taken into account when considering how best to support children with different performance levels in the classroom. In teacher education, it should be emphasized that it is important that teachers support children and their developing self-concept, and not only teach children new academic skills. Moreover, the results of the present study indicate that for low-performers the role of teachers' beliefs in self-concept development is not positive, as it is for high-performing students. Although it would seem that high- and low-performers may benefit from different kinds of teacher support, further studies are needed to ascertain the mechanism behind the associations reported in the present study. For example, one further line of research is to clarify to what extent teachers' beliefs are reflected in the feedback they give students and whether low-performing children would benefit, for example, from more specific feedback rather than feedback on domain-specific skills in general.

Overall, the results of the present study suggest that during the first grade it is teachers' beliefs, in particular, that play a role in children's self-concept of ability. However, the connection between teachers' beliefs and children's self-concept of ability seems to differ depending on the level of the child's performance. 


\section{References}

Aiken, L. S., \& West, S. G. (1991). Multiple Regression: Testing and interpreting interactions. Newbury Park, CA: Sage.

Ambady, N., Shih, M., Kim, A., \& Pittinsky, T. L. (2001). Stereotype susceptibility in children: Effects of identity activation on quantitative performance. Psychological Science, 12, 385-390. doi: $10.1111 / 1467-9280.00371$

Arens, A. K., Yeung, A. S., Craven, R. G., \& Hasselhorn, M. (2011). The twofold multidimensionality of academic self-concept: Domain specificity and separation between competence and affect components. Journal of Educational Psychology, 103, 970-981. doi: 10.1037/a0025047

Atkinson, J. W. (1964). An introduction to motivation. Princeton, NJ: Van Nostrand.

Aunola, K., Leskinen, E., Onatsu-Arvilommi, T., \& Nurmi, J-E. (2002). Three methods for studying developmental change: A case of reading skills and self-concept. British Journal of Educational Psychology, 72, 343-364. doi: 10.1348/000709902320634447

Bandura, A. (1986). Social foundations of thought and action: A social cognitive theory. Englewood Cliffs, NJ: Prentice-Hall.

Blumenfeld, P. C., Pintrich, P. R., Meece, J., \& Wessels, K. (1982). The formation and role of self perceptions of ability in elementary classrooms. The Elementary School Journal, 82, 400-420. doi: $10.1086 / 461278$

Blöte, A. (1995). Students' self-concept in relation to perceived differential teacher treatment. Learning and Instruction, 5, 221-236. doi: 10.1016/0959-4752(95)00012-R

Bohlmann, N., \& Weinstein, R. (2013). Classroom context, teacher expectations, and cognitive level: Predicting children's math ability judgments. Journal of Applied Developmental Psychology, 34, 288-298. doi: 10.1016/j.appdev.2013.06.003 
Bong, M., \& Skaalvik, E. M. (2003). Academic self-concept and self-efficacy: How different are they really? Educational Psychology Review, 15, 1-40. doi: 10.1023/A:1021302408382

Brattesani, K., Weinstein, R., \& Marshall, H. (1984). Student perceptions of differential teacher treatment as moderators of teacher expectation effects. Journal of Educational Psychology, 76, 236-247. doi: 10.1037/0022-0663.76.2.236

Burnett, P. C. (2003). The impact of teacher feedback on student self-talk and self-concept in reading and mathematics. Journal of Classroom Interaction, 38, 11-16.

Dermitzaki, I., \& Efklides, A. (2000). Aspects of self-concept and their relationship to language performance and verbal reasoning ability. The American Journal of Psychology, 113, 621637. doi: $10.2307 / 1423475$

Dweck, C. S. (2002). The development of ability conceptions. In A. Wigfield \& J. S. Eccles (Eds.), Development of achievement motivation (pp. 57-88). San Diego, CA: Academic Press.

Eccles, J. S. (1993). School and family effects on the ontogeny of children's interests, self-perceptions, and activity choices. In J. E. Jacobs \& R. Dienstbier (Eds.), Developmental perspectives on motivation (pp. 145-208). University of Nebraska Press.

Eccles, J. S., Adler, T. F., Futterman, R., Goff, S. B., Kaczala, C. M., Meece, J. L., \& Midgley, C. (1983). Expectancies, values, and academic behaviors. In J. T. Spence (Ed.), Achievement and achievement motivation (pp. 75-146). San Francisco: W. H. Freeman.

Eccles Parsons, J., Adler, T. F., \& Kaczala, C. M. (1982). Socialization of achievement attitudes and beliefs: Parental influences. Child Development, 53, 310-321. doi: 10.2307/1128973

Eccles, J. S., \& Jacobs, J. E. (1987). Social forces shape math attitudes and performance. In M. R. Walsh (Ed.), The psychology of women: Ongoing debate (pp. 341-354). New Haven, US: Yale University Press. 
Eccles, J. S., \& Wigfield, A. (1995). In the mind of the actor: The structure of adolescents' achievement task values and expectancy-related beliefs. Personality and Social Psychology Bulletin, 3, 215-225. doi: 10.1177/0146167295213003

Frome, P. M., \& Eccles, J. S. (1998). Parents' influence on children's achievement-related perceptions. Journal of Personality and Social Psychology, 74, 435-452. doi: 10.1037/0022-3514.74.2.435 Gniewosz, B., Eccles, J. S., \& Noack, P. (2012). Secondary school transition and the use of different sources of information for the construction of the academic self-concept. Social Development, 21, 537-557. doi: 10.1111/j.1467-9507.2011.00635.x

Gniewosz, B., Eccles, J. S., \& Noack, P. (2014). Early adolescents' development of academic selfconcept and intrinsic task value: The role of contextual feedback. Journal of Research on Adolescence, 25, 1-15. doi: 10.1111/jora.12140.

Gunderson, E. A., Ramirez, G., Levine, S. C., \& Beilock, S. I. (2012). The role of parents and teachers in the development of gender-related math attitudes. Sex Roles, 66, 156-166. doi: $10.1007 / \mathrm{s} 11199-011-9996-2$

Harter, S. (1982). The Perceived Competence Scale for Children. Child Development, 53, 87-97. doi: $10.2307 / 1129640$.

Hoge, R. D., \& Coladarci, T. (1989). Teacher-based judgements of academic achievement: A review of literature. Review of Educational Research, 59, 297-313. doi: 10.2307/1170184

Ikäheimo, H. (1996). Diagnostic test for basic mathematical concepts. Helsinki, Finland: Oy OPPERI $\mathrm{Ab}$.

Jacobs, J. E. (1991). Influence of gender stereotypes on parent and child mathematics attitudes. Journal of Educational Psychology, 83, 518-527. doi: 10.1037/0022-0663.83.4.518 
Jacobs, J. E., Lanza, S., Osgood, D. W., Eccles, J. S., \& Wigfield, A. (2002). Changes in children's self-competence and values: Gender and domain differences across grades one through twelve. Child Development, 73, 509-527. doi: 10.1111/1467-8624.00421

Jerome, E. M., Hamre, B. K., \& Pianta, R. C. (2009). Teacher-child relationships from kindergarten to sixth grade: Early childhood predictors of teacher-perceived conflict and closeness. Social Development, 18, 915-945. doi: 10.1111/sode.2009.18.issue-410.1111/j.14679507.2008.00508.x

Lau, S., \& Pun, K-T. (1999). Parental evaluations and their agreement: Relationship with children's self-concepts. Social Behavior and Personality, 27, 639-650. doi: 10.2224/sbp.1999.27.6.639

Lehtinen, E., Vauras, M., Salonen, P., Olkinuora, E., \& Kinnunen, R. (1995). Long-term development of learning activity: Motivational, cognitive, and social interaction. Educational Psychologist, 30, 21-35.doi: 10.1207/s15326985ep3001_3

Leppänen, U., Niemi, P., Aunola, K., \& Nurmi, J. (2004). Development of reading skills among preschool and primary school pupils. Reading Research Quarterly, 39, 72-93. doi: 10.1598/RRQ.39.1.5

Li, Q. (1999). Teachers' beliefs and gender differences in mathematics: A review. Educational Research, 41, 63-76. doi: 10.1080/0013188990410106

Madon, S., Smith, A., Jussim, L., Russell, D. W., Eccles, J., Palumbo, P., \& Walkiewicz, M. (2001). Am I as you see me or do you see me as I am? Self-fulfilling prophecies and self-verification. Personality and Social Psychology Bulletin, 27, 1214-1224. doi: 10.1177/0146167201279013 
Marsh, H. W., \& O’Neill, $R$. (1984). Self-Description Questionnaire III: The construct validity of multidimensional self-concept ratings by late adolescents. Journal of Educational Measurement, 21, 153-174. doi: 10.1111/j.1745-3984.1984.tb00227.x

McGrath, E. P., \& Repetti, R. L. (2000). Mothers' and fathers' attitudes toward their children's academic performance and children's perceptions of their academic competence. Journal of Youth and Adolescence, 29, 713-723. doi: 10.1023/A:1026460007421

Parrila, R., Aunola, K., Leskinen, E., Nurmi, J.-E., \& Kirby, J. (2005). Development of individual differences in reading: Results from two longitudinal studies. Journal of Educational Psychology, 97, 299-319. doi: 10.1037/0022-0663.97.3.299

Phillips, D. A. (1987). Socialization of perceived academic competence among highly competent children. Child Development, 58, 1308-1320. doi: 10.2307/1130623

Rost, D. H., \& Hanses, P. (1997). Not achieving—not gifted? About the identification of gifted underachievers by teacher-ratings. Zeitschrift fuer Entwicklungspsychologie und Paedagogische Psychologie, 39, 167-177.

Rytkönen, K., Aunola, K., \& Nurmi, J. (2007). Do parents' causal attributions predict accuracy or bias in their children's self-concept of math ability? A longitudinal study. Educational Psychology, 27, 771-788. doi: 10.1080/01443410701309316

Shavelson. R. J., Hubner, J. J., \& Stanton, G. C. (1976). Self-concept: Validation of Construct Interpretations. Review of Educational Research, 46, 407-441. doi: 10.2307/1170010

Simpkins, S. D., Fredricks, J. A., \& Eccles, J. S. (2012). Charting the Eccles' expectancy-value model from mothers' beliefs in childhood to youths' activities in adolescence. Developmental Psychology, 48, 1019-1032. doi: 10.1037/a0027468 
Spinath, B., \& Spinath, F. M. (2005). Longitudinal analysis of the link between learning motivation and competence beliefs among elementary school children. Learning and Instruction, 15, 87102. doi: 10.1016/j.learninstruc.2005.04.008

Tiedemann, J. (2000). Parents' gender stereotypes and teachers' beliefs as predictors of children's concept of their mathematical ability in elementary school. Journal of Educational Psychology, 92, 144-151. doi: 10.1037/0022-0663.92.1.144

Wells, C. S., \& Wollack, J. A. (2003). An instructor's guide to understanding test reliability. Testing \& Evaluation Services publication, University of Wisconsin.

Wigfield, A., \& Eccles, J. S. (1992). The development of achievement task values: A theoretical analysis. Developmental Review, 12, 1-46. doi: 10.1016/0273-2297(92)90011-P

Wigfield, A., \& Eccles, J. S. (2000). Expectancy-value theory of achievement motivation. Contemporary Educational Psychology, 25, 68-81. doi: 10.1006/ceps.1999.1015

Wigfield, A., Eccles, J. S., Schiefele, U, Roeser, R. W., \& Davis-Kean, P. (2006). Development of achievement motivation. In N. Eisenberg, W. Damon \& R. M. Lerner (Eds.), Handbook of child psychology: Vol. 3, Social, emotional, and personality development (6th Ed.) (pp. 933-1002). Hoboken, NJ, US: John Wiley \& Sons Inc. doi: 10.1002/9780470147658.chpsy0118

Wigfield, A., Eccles, J. S., Yoon, K. S., Harold, R. D., Arbreton, A. J. A., Freeman-Doan, C., \& Blumenfeld, P. C. (1997). Change in children's competence beliefs and subjective task values across the elementary school years: A 3-year study. Journal of Educational Psychology, 89, 451-469. doi: 10.1037/0022-0663.89.3.451

Wigfield, A., \& Harold, R. D. (1992). Teacher beliefs and children's achievement self-perceptions: A developmental perspective. In D. H. Schunk, \& J. L. Meece (Eds.), Student perceptions in the classroom (pp. 95-122). Lawrence Erlbaum Associates, Hillsdale, New Jersey. 